\title{
Liminality, Migration and Transgression in El Metro by Donato Ndongo-Bidyogo
}

Carles Magrinyà

Dalarna University and Uppsala University

\section{Introduction}

The representations of liminality in different categories are relevant when they highlight a transitory state, that is, a transformation from one state to another, or when a long situation between two states stands out. The concept, close to others like border or hybridity, is implicitly present in El Metro (The Subway, 2007) by Donato Ndongo-Bidyogo at different levels: in the representation of spaces, characters, and cultural space on the hand, and in the functions of the narrator on the other. The objective of this chapter is to contribute to the understanding of the functionality of the fictional border spaces and the ways to represent them. It examines how the protagonist and the narrator perceive and relate to these liminal spaces, and evaluates their function and significance.

El Metro by the Equatoguinean writer Donato NdongoBidyogo, published in 2007 , is a Bildungsroman that addresses the issue of migration. It relates the biography and journey of a young Cameroonian forced to leave his village after a conflict with his father and his community, until arriving in Spain illegally in search of a better life. The vicissitudes of the protagonist, Lambert Obama, may be seen as that of the present-day African everyman. It is thus relevant to study this novel firstly in the context of globalism and migration from Sub-Saharan Africa to South

How to cite this book chapter:

Magrinyà, C. 202I. Liminality, Migration and Transgression in El Metro by Donato Ndongo-Bidyogo. In: Jonsson, H., Berg, L., Edfeldt, C. and Jansson, B. G. (eds.) Narratives Crossing Borders: The Dynamics of Cultural Interaction. Pp. 339-356. Stockholm: Stockholm University Press. DOI: https://doi.org/Io.I6993/bbj.o. License: CC-BY 4.0 
Europe; and secondly, as an example of the relatively unknown Afro-Hispanic novel from Equatorial Guinea, often ignored by academia. $^{\mathrm{I}}$

The novel displays a clear tone of social criticism questioning the conflict between tradition in Sub-Saharan Africa - i.e., religious beliefs, social structures of groups, taboos, etc. - and modernity, i.e. changes and values brought first by colonialism, and later on by neocolonialism and globalism. The ultimate aim of the novel, as the author has explicitly reported (García, 2007), is to denounce current events in which migrants find themselves involved, and to criticize and report on the situation of the contemporary subSaharan African. As for the writer's role, like the traditional African storyteller, it becomes for Ndongo that of a spokesperson for the society where he lives and a representative of the community to which he belongs. Consequently, writers are always bearers of meaning and identity so that an author is not perceived as a distant individual. Literature is not solely an aesthetic expression but it serves the community, and its main objective is to denounce a situation, be it economic, political or religious. Ndongo himself has stated: "[i]n the Fang ethnic group ${ }^{2}$, to which I belong, there is no art for art's sake, but it has to be useful, as well as beautiful. My books are a proposal for taking action to solve the problems that afflict this generation of Africans" (García, 2007)3. The role of contemporary African writers according to Ndongo is that of custodians of the collective memory. Oral literatures do not survive or end up distorted, but writing them is a step in preserving

${ }^{\text {I }}$ It is not common to study Equatoguinean literature in Spanish at Spanishspeaking universities, but it is becoming increasingly common in the USA. Ndongo's works are widely read in Gabon, Ivory Coast, or Madagascar. Chronologically, the literary production from Equatorial Guinea is later than Negritude, and its thematic orientation is different. The largest production of works of literature has been since the beginning of the I990s until today.

2 The Fang people are a Central-African ethnic group found in Equatorial Guinea, northern Gabon, and Southern Cameroon (Lyle, 2002, p. 72).

3 "En la etnia fang a la que pertenezco, no existe el arte por el arte, sino que tiene que ser útil, además de bello. Mis libros son una propuesta de acción para que se resuelvan los problemas que aquejan a esta generación de africanos". 
traditions and finding new ways of telling stories. This symbiosis already exists in the presence of the genres in the novel, blending aspects of the novel of European background - Bildungsroman with those of the literature of African oral tradition, for example, in the representation of the narrator, as we shall see.

El Metro has an "epic" and initiatic structure (departure, initiation, return) in a journey that emphasizes the dangers and fears of the main character. In this sense, the spaces that involve some form of intermediate or border state for the characters, that is, some kind of threshold, are particularly interesting to study due to their dynamism. Examples of such spaces are pilgrimage sites, gardens, beaches, vehicles, boats, subways, and caves.

Following the conceptual and terminological contributions coined more than a century ago by the anthropologists Arnold Van Gennep and the later elaboration of Víctor Turner, we define the spaces that have those traits in El Metro as liminal, proving that they are often associated with situations of tension and fear for the protagonist. Therefore, it is logical to state that they comprise scenarios full of tension, where vital options open or close for the characters.

\section{Approaching Liminality}

Even though liminality does not refer necessarily to space, the very notion itself derives etymologically (limen signifies "threshold" in Latin) from the realms of space and territory. In anthropology, the concept of liminality is used to analyze transformations of identities, interactions between identities and intermediate zones. Since its introduction, several studies have been published in which the concept is applied both to literature in general and to specific literary works. ${ }^{5}$

In his foundational work The Rites of Passage from 1909, Van Gennep established a solid structure with a series of transitions that affect the individual in his social development in relation to his

4 The main study regarding the concept of liminality is Turner, Victor W in The Ritual Process: Structure and Anti-Structure, from I966.

5 Among them, Pérez Firmat (I986), Ashley (I990), Spariosu (I997), Viljoen, Hein \& Chris van der Merwe (2006), Phillips (201 5 ). 
life cycle and family: for example, between youth and adulthood, between being single and being married, between not belonging and belonging to a group, between traveling and returning. Van Gennep distinguished three phases in a rite of passage: I) preliminal rites, or separation 2) liminal rites (the interstitial phase), or margin; and 3) postliminal rites, or aggregation (Van Gennep, 2008). The first phase is a symbolic death, since the initiate is detached from his environment in which he must break with previous practices and routines. The next stage is ambiguous for the aspirant. While this transition takes place, the novice remains between one identity and another; he passes through a cultural realm that has few or none of the attributes of the past or coming state. In the stage of aggregation, the initiate has crossed the threshold of the rite, returns to society, and acquires a new way of being. He is expected to behave in accordance with certain customary norms and ethical standards. Turner emphasized the importance of this middle stage of liminality for its ambiguity, ambivalence and instability. According to Turner, liminality facilitates a space of a social anti-structure in opposition to the hierarchic structure of the regular life (I99I, p. I05). Thus, liminality acquires its own autonomy, as with, for example, during courtship - the transitory state between being single and marriage. However, liminality is not exclusive to the second phase in a rite of passage. Since Turner, the concept has been used in other disciplines such as cultural and postcolonial studies (Bhabha, I994), highlighting a realm of new possibilities where new cultural expressions can be tested. In postcolonial studies, the concept is used to circumscribe a being on the border, marginal, or on the threshold, dividing distinct spheres, identities or discourses.

In literary works, the term also concerns aspects of space, time, the state of the characters, etc., characterized by indeterminacy, ambiguity, hybridity, and potential for creating a new identity. A liminal boundary is "where something ends, but also where something new may begin. [...]. This usually happens at places (doors or gates) where one is allowed to cross the boundary" (Spariosu, I997, p. I0). The notion of space has produced new metaphors and names in contemporary literary studies: interstitial, limits, in-between, border zones. Although the interdisciplinary use of 
these concepts is potentially fruitful, it is important to concretize and delimit the framework in order to avoid endless equivocal interpretations. We will refer mainly to Turner's work because even though the concept of liminality has its roots in anthropology, it is applicable in a literary discourse.

\section{Ritual and Transgression}

The first part of the novel focuses on the colonization of Cameroon by the French. As mentioned, the conflict between tradition and modernity is nuclear in this novel, and it is in this sense that the departure of the protagonist from his village is to be understood. His grandfather, Ebang Motuú, is the leader of the Yendok clan, a man symbolizing the colonial experience, as well as the resistance against the colonial administration. Lambert's father, Guy Ondo Ebang, on the contrary, becomes a Catholic priest, and represents the black man's adoption of the white man's ways. The culture clash is thus defined between traditional pagan and Catholic cosmogonies, although the question may be raised as to whether or not the latter is modern.

Lambert Obama Ondo, our protagonist, breaks off with the logic of his community and rejects his father's mimicry and aping of the imperial master - mimicry here becomes mockery and is at once resemblance and menace (Bhabha, I994, p. 86). When his mother dies, his father begins a relationship with another woman whose daughter is Lambert's lover. The daughter then becomes pregnant by Lambert. The leaders of the community do not accept Lambert's request of marriage, that is to say, a rite of passage and a temporal border crucial for his evolution in the community, judging their relationship as incestuous. In the light of this refusal, the protagonist decides to flee in search of a better future, in a moment of epiphany: "Lambert Obama dismantled his spirit to the myths of yesterday to travel extensively in search of new horizons. It was necessary to be reborn" (p. I73). ${ }^{6}$ This selection of words, of initiatory connotations (die - reborn), also refers to the

6 "Lambert Obama desmontó de su espíritu los mitos del ayer para peregrinar a la búsqueda de nuevos horizontes. Era preciso renacer para vivir". 
transitory stage in which he enters: "Obama Ondo felt the transition [emphasis mine], which shook the essence of his existence and swept away all his convictions like the prologue to an era of instability (p. I73). ${ }^{7}$ In this particular case, we have to take into consideration the polysemy in the original Spanish version in the words in italic, pointing at the decisive moment in which the character makes the decision to abandon his cultural identity. It involves not only a transformation and transgression, but also the seed of the internal conflict that many African migrants experience, with the paradox that the moral limits of their community are what at the same time constitute their identity. This moment of rupture of the social structure is when the separation takes place that leads to entry into the liminal state. That is, the fact of not being able to consummate a marriage - a rite of passage - is what causes our protagonist to wander endlessly and become socially ambiguous - "between and betwixt" to use Turner's words.

Turner describes this state as a "realm of pure possibility" (I970, p. IOI), where people can abandon their social conditioning and constitute a new space. The individual develops a social critique, as well as a sense of non-belonging or of not occupying any symbolic space in the social structure: "and he knew that he had descended the last steps of the social ladder, he had ceased to be a free man worthy of respect" $(\mathrm{p} . \mathrm{I} 75)^{8}$. This revelation occurs in an episode in a space with liminal connotations: in the central market of the Yaoundé city, a transit point, and at an intermediate time, at dawn (between night and day). From this moment, the search for new cultural meaning will be in the dialectic between tradition and modernity. Lambert is therefore outside of the social structure when he moves to the capital of Cameroon, a dirty, insecure, and stressful place where its inhabitants focus only on their own interests and prioritize materialism. The action moves to urban spaces that work more like locus horribilis in contrast with the idyllic memory of the village, an unattainable yet idealized

7 “Obama Ondo percibía aquel trance [tránsito] que conmocionaba su esencia y barría todas sus convicciones como el prólogo de una era de inestabilidad".

8 "y supo que había descendido los últimos peldaños de la escala social, había dejado de ser un hombre libre digno de respeto". 
locus amoenus. For instance, rite is subverted in the city and materialism is not antithetical to religious practices. It is not that the inhabitants of the city have turned their backs on the supernatural; on the contrary, they perform rituals and use spells and amulets for the satisfaction of their ambitions. Those responsible for materializing the desires of the avid are sorcerers who really have a power, "evu" (p. I 86), that allows them to satisfy all their needs in exchange for human sacrifices. Politicians, governors, and senior executives turn to these sorcerers to achieve their goals. Lambert's idea of the village is now more myth than reality, because the life of his community relies on outdated values: "What other horizons could an entire people condemned exclusively to survive glimpse? To preserve the fiction of dead traditions, incapable of lasting? [...] To embrace a suffocating and alienating modernity, which leaves no room for the building and development of one's own personality?"'(p. 200). 9 The thought of the self-sufficient peasant is only an idealization in contrast with crude reality that pushes many young people to flee from the countryside to the city in search of well-being and happiness.

The conflict between tradition and modernity is also represented in the situation of women. It is interesting that the character of Danielle, a lover of Lambert, is an example of a hybrid subject. For her, the perfect man is a synthesis of African and European, a man who mixes equal doses of emotion and logic. She is a modern woman married to a rich man, who has become rich at the expense of the government. Danielle, however, represents the illusion that wealth provides freedom. The taboos of tradition are socially rooted, such as in the example of the impossibility of divorce. Something strongly symbolic is the use of products for skin whitening. She is another ambivalent subject, isolated physically and psychologically from her community, in the bubble of an ostentatious life.

9 “¿Qué otros horizontes podía vislumbrar todo un pueblo condenado exclusivamente a sobrevivir? ¿Conservar la ficción de unas tradiciones muertas, incapaces de perdurar [...]? ¿Abrazar una modernidad asfixiante y alienante, que no deja resquicio alguno para la construcción y el desarrollo de la propia personalidad?" 


\section{Liminal Spaces and Other Realms of Reality}

There is, in fact, no clear and final destination in Lambert's journey, unlike the route of a pilgrimage. His wandering is characterized by spontaneous and unexpected events, and the structure of the story unfolds as the crossing of geographical borders and as changes in location occur. From Yaoundé in Cameroon, Lambert crosses the first national border by boat to Dakar, Senegal, where he gets enough money to embark on an illegal trip to Europe organized by networks of illegal-migrant smuggling mafias. Then he arrives in Casablanca in Morocco and El Aaïun in the Western Sahara, a territory disputed over by Morocco and Mauritania during the process of the decolonization of Spain. ${ }^{\circ}$ As such, another aspect of liminality takes place, considering that liminal spaces go from borders to disputed territories (Rogers, I997, p. 528; Shcimanski and Wolfe, 20I7, p. I 56-I57). It is in this liminal space that he embarks a small boat ("patera") and arrives at Arrecife, a city on Lanzarote in the Canary Islands. The arrival on the beaches of the Canary Islands is significant and symbolic: it involves the arrival of the longed-for continent and, on the other hand, it also symbolizes the convergence of the two continents - a Spanish territory in Africa, a third space imagined as Ugarte suggests, between Africa and Europe (2010, p. 8I). ${ }^{\text {II }}$

As we can see, Lambert Obama crosses the sea twice, all in difficult conditions: firstly, on a ship transporting wood from Douala (Cameroon) to Dakar (Senegal); secondly, in the painful crossing inside the small boat, before arriving in Spain, showing the torments that migrants suffer prior to arrival at the point of destination. In these episodes, the ship is the space of the character in a psychological liminal state, between wakefulness and sleep. ${ }^{\mathrm{I} 2}$

ro Western Sahara was occupied by Spain until the late $20^{\text {th }}$ century, and the decolonization process was interrupted in 1976 when its managing power, Spain, left Western Sahara in the hands of Morocco and Mauritania.

II Spain is seen by Africans as a gateway nation, a stepping stone for migrants to move illegally from Africa to Europe. Many initiatives have been made by the Government of Spain since the end of the last century to control immigration, including agreements with Senegal and Morocco that restrict and normalize migration to Spain from Africa (Ugarte, 20IO: 78).

${ }^{\text {I2 }}$ Ndongo had already written about these themes in his first short story, "El sueño" (The Dream, I973). It relates the epic trip and experience 
In the first sea trip, he sneaks onto the ship and must remain hidden, and what characterizes the episode is indeterminacy, total disorientation, and the loss of the sense of time. He does not know either where he is going or how long the trip will take, or whether he is awake or asleep. Claustrophobia, loneliness, and the sensation of a living hell while inside a dark cave lead to a chain of thoughts about the difficulties of this trip taking into account the conditions of his ancestors during the Atlantic Slave Trade. ${ }^{\mathrm{I} 3}$ The second route recounts the hard trip with a small boat ("patera") prepared for ten people loaded with thirty-six men and women, extremely cold nights, sub-human conditions of hygiene, deaths of several passengers. These moments of disorientation, loneliness, restlessness and ambiguity are those of liminal situations, according to the notion of liminoid persons of Turner. ${ }^{14}$ This type of person can experience the vision of entities such as guides or counselors; legendary beings of ambiguous and hybrid nature can be represented in the liminal experience with the co-presence of opposites (high / low, good / bad).

The function of the maritime chronotope of the ship proves significant, as it appears in the novels during a time of crisis for the main character. Aware of the dangers of the sea, in both trajectories the protagonist relies on his ancestors. It is worth paying attention to the first sea trip when he performs some kind of ritual that is syncretic in nature and that invokes at the same time a pagan divinity and the Christian God (he will perform another animist ritual to recover from a disease) in an example of trans-religious spirituality. The reader is referred to the domain of cultural hybridity of the protagonist:

In his light sleep, before falling into lethargy, the astonishing visions of his grandfather and his mother appeared again, surrounded by a myriad aura, and repeated incessantly, do not distress yourself, son, you have finally arrived safe and sound to the distant

of hardship of a young Senegalese traveling from Senegal to Dakar, the Canary Islands, Barcelona and France.

${ }^{13}$ Koné studied the symbolism of the boat in El Metro (2015).

${ }^{14}$ The concept liminoid is restrictively applied to the quality of liminar in contemporary Western world, while the liminal points out to states and rites in tribal societies (Deflem, I99I, p. I 5 ). 
port of destination. And he knew with certainty that during the unfortunate journey he had been protected at every moment by the spirits of his elders (p. 354). ${ }^{15}$

While he is in a light stage of sleep, the intermediate time between sleep and wakefulness, the teachings from his tradition in the form of aphorisms and proverbs come to his consciousness. The use of adjectives related to light, darkness, and dawn, along with metaphors about the shadows of the soul, point at a setting marked by liminality.

Turner notes that the absolute authority of the elders in the liminal state represent the values of a given society and that they provide the esoteric instructions in the sacra realm (I970, pp. 102-106). It is in the decisive moments, in situations of danger, that the spiritual world bursts into the material, naturally, without being perceived as something extraordinary. The process by which the ancestors and the forces of nature are in permanent contact with man has been called African animist realism (Nomo, 2004; Melo, 2009, pp. I I6-II8). Hauntings are also figurations of the temporal border between the living and the dead (Schimanski and Wolfe, 2017, p. I63), and a form of border beings that appear in the liminal state. If an eschatological space is in the afterlife, liminality will imply then a border zone, a place where the natural and the supernatural coexist ${ }^{16}$, represented here through the convergence of the chronotopes of the threshold and the boat. Indeed, Koné (2OI 5 ) has pointed out the importance of the chronotope of the boat, but as we shall see, the irruption of the supernatural is an essential requisite for the resolution of the plot.

Once in Madrid - this time, a longed for city - the interior spaces take a central role together with themes like alienation

is "En el duermevela, antes de caer en el letargo, se le aparecieron de nuevo las asombrosas visiones de su abuelo y de su madre, circundados por un aura mirífica, que le repetían incesantemente no te angusties, hijo, por fin has llegado sano y salvo al lejano puerto de destino. Y supo con toda certeza que a lo largo de aquel periplo infausto había estado protegido en cada instante por los espíritus de sus idos."

${ }^{16}$ The notion is similar to what Henry Corbin named mundus imaginalis (2006, pp. 24-26), a sacred and intermediate double-space where the terrestrial and celestial worlds collide. 
and claustrophobia. The protagonist spends the last moments of his life in the underground tunnels of metro stations, selling trinkets. A group of skinheads inside a train carriage beat him to death. This series of interior spaces is nuclear because it is where the action of the novel begins and ends (chapter I connects with chapter I9), and in addition it is the title of the novel.

The abundance of explicit and symbolic references to light and darkness in the last city in the novel should be highlighted. The passages of the underground world evoke and actualize the classic motif of the catabasis ${ }^{17}$ and adventure into the underworld (descensus ad inferos). The journey into the world of the dead, in which the hero, through a cave, traveled to the Hereafter, had to undergo an initiatory test and returned, improved, to relate what he had seen (Piñero, I995, p. 8). These are moments of deep psychological introspection into an unknown place. In this episode, the selection of words condenses a set of contrasts pivotal to the inventio of the text, between light and darkness in a binary opposition that has been gradually taking shape throughout the novel for instance, between the natural darkness of the underground, the "underworld", and the artificial light of the underground city, as Ugarte suggests (2010, p. 82). In addition, the opposition between the darkness and the light of the world outside can be seen in the following specific instances: Lambert meets Lucía (a feminine noun meaning 'light', from the Latin $\operatorname{lux}$ ); it is said that her beauty would "dazzle"(deslumbraría, p. 452) him; he sells small trinkets near Lucero (Venus, "morning star") metro station or near Puerta del Sol (Sun Gate), in a quote that foreshadows the end of the novel: "from Madrid to Heaven, he had heard from the elders of the place [Madrid]) (p. I9). ${ }^{18}$ There is even a quote that quickly connects intertextually with Joseph Conrad's Heart of Darkness: "He came from the cursed land, Africa, the continent of eternal night, heart of darkness" (p. 2I). ${ }^{19}$ These words are part of a long reflection on alienation in terms of what it means to be black in Europe, the collective past of slavery, and the difficulty but also

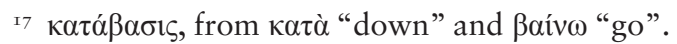

I8 “de Madrid al Cielo, había oído a los más viejos del lugar”.

is "Procedía de la tierra maldita, África, el continente de la noche eterna, el corazón de las tinieblas”.
} 
the possibility of realizing his own individuality, with plenty of dualities. This reference is not accidental; indeed, Conrad's work left its mark on Ndongo and was decisive for his career (Otabela and Onomo, 2008, p. 4I).

In the description of the liminal state, Turner points out that the attributes of the liminal personae ("threshold people") are ambiguous, expressed by a variety of symbols associated with death, being in the womb, darkness and wilderness, among others (I99I, p. 95). Moreover, in the description of the subterranean world of Madrid the protagonist identifies with a "grombif", a giant field rat of his country, in a simile that expresses his progressive dehumanization. He sees himself transformed into this strange being, a hybrid in Turner's terms, half human and half animal, that in the evening looks for its den under the tunnels of Madrid. This metaphoric mental space is thus for Lambert the border zone, the state in which the old and the new coexist. The underground world on the other hand is analogous to a cave, whose function is as threshold to the supernatural or Hereafter, as the final paragraph vividly demonstrates:

His last image, perceived by his conscious mind or perhaps with the eyes of the soul already in the world of the dead, was the luminous face of his mother ... who stretched out to him her glistening arms for taking him under her wing ${ }^{20}$, while the firm and serene voice of his grandfather wrapped him in a prodigious tranquility, and told him "do not be afraid, son: at last you have reached the port of destination, and your death will not be anonymous" (p. 458).

Our protagonist left the community in the first phase and experienced the second phase under the direction of his ancestors, suffering from increasing fear and the different tests. At this point,

20 "Su postrera imagen, captada por su mente consciente o quizá con los ojos del alma ya en el mundo de los idos, fue el del rostro luminoso de su madre ... que extendía hacia él sus brazos refulgentes para recibirle en su seno [emphasis mine], mientras le envolvía en una placidez prodigiosa la voz firme y serena de su abuelo ... y le decía no tengas miedo, hijo: al fin has llegado al puerto de destino, y tu muerte no será una muerte anónima”.

'Seno' in Spanish can also mean 'family', 'maternal womb', 'mother's breast', 'protection', 'bosom'. 
the liminal phase ends and he enters into the last phase. The last stage is not the end of a formal rite but the coming of death with the subsequent reunion with his grandfather and mother.

What happens in our protagonist's transit to the world of the dead is, however, similar to rites that include the symbolic return to the uterus (regressus ad uterum). In this sense, the historian of religion Mirce Eliade studied the symbolism of rituals of initiation that implied a return to the embryonic state that enables a higher mode of existence (Allen, I998, p. 245). The regressus ad uterum takes place, in many cases, under the earth, because this is the element or materia prima with which man has been created. Concomitantly, the liminal state is associated with death, darkness, and the womb, as we have mentioned. The postliminary stage or aggregation in Lambert, the regressus ad uterum to her mother, is marked by a real and unsymbolic death, since the return to his home and community, both psychologically and sociologically, takes place at a metaphysical level.

Lambert is a "product" of colonial past and hybridity, that is, a process by which he challenges the authenticity of any essentialist identity. Migration, transformation, social liminality can lead to a new cultural synthesis and integration in the dimension of a new 'third space' (Bhabha, I994: 5). As a migrant, being in an 'in-between' space opens up creativity and ideas as to what his new role must be: for instance, combating stereotypes, and finding a solution to the conflict between the modern world and the traditional world, racism and multiculturalism (3 II); or, instead of becoming one with the prosperity of the West, uniting with his countrymen to fight for freedom and liberty (p. 447; O'Connor, $2009, \mathrm{p} .3)$. This new third space of possibilities that Lambert has is abruptly demolished in the last chapter.

\section{Narrative Transgressions}

Given the number of mentions to light and darkness, the heterodiegetic narrator suggests that Lambert wandered in a dark and confused world - the impossibility of creating a third space out of the duality modernity/tradition, something like "he had walked through darkness and now sees the light". The constant presence of the symmetry lux / tenebras and the very last paragraph of the 
novel in the last moments before death actualize and allude to the biblical Post tenebras spero lucem (Job, I7.I2) 2I ("After darkness, I hope for light"). The act of adopting another identity is a crossing towards another shore, leaving behind a frustrated hybridity. Thus, the search for light - knowledge, truth - is expressed in what will be the last words of our mysterious narrator.

As in the African oral tradition, the story is delivered by a plurality of voices under the control of an omniscient and hetero-diegetic narrator, in control of all the narrative material. The narrator represents the figure of the "Mvet", "Mbom Mvet" 22 or "griot", a kind of troubadour from precolonial times who relates legends, stories of the tribes, and the heroic life of charismatic leaders, with the purpose of advising and exhorting his community (Hale, 2007: 24-40).

The use of normal indirect speech and above all free indirect style with the subsequent almost absolute absence of verba dicen$d i$ (they only appear in the visions of Lambert) is used on entire pages of rhetorical questions on issues such as colonization, the situation of neocolonial Africa, and paganism and superstitions. Otabela and Onomo (2008, p. I4I) give an account of 374 cases of rhetorical questions (those that stand out are chapter 8,38 cases; chapter I4, 45 cases; and chapter I 8, 56 cases) and point out that these are also present in the para-text, concretely on the back cover ("What drives so many Africans to flee from their country and emigrate to the North? What is the price of this uprooting?). ${ }^{23}$ At times, the voice of the protagonist fuses with that of the narrator (Ugarte, 20I0: 84). In some instances, the criticism about neocolonialism - here, corrupted African governments under the tutelage of the West - takes the form of a short essay. Thus, the use of free indirect style results in an ambiguity that gives greater emancipation to the narrator, transgressing the limits of the diegesis - or textual borders - and making it difficult to differentiate between

\footnotetext{
${ }_{21}^{2}$ "Noctem verterunt in diem et rursum post tenebras spero lucem". The mottto was adopted later on by reformer John Calvin - Post tenebras lux.

${ }_{22}$ "Mvet" is a noun that refers to a traditional guitar from the ethnic group Fang; "Mbom vet" designates the player of this instrument (Otabela \& Onomo, 2008: I 5 ).

23 “¿Qué impulsa a tantos africanos a huir de su tierra y emigrar al norte? ¿cuál es el precio de este desarraigo?”
} 
diegetic levels. The result is an effective blending, also liminal in a sense, of free indirect style and inner monologue. I believe that in relation to the narrative transgressions of this novel, it is relevant to recall Genette's main idea of narrative metalepsis (I980, pp. 234-235), that is, the crossing or transgression of diegetic levels, blurring the narrative levels as well as the line between reality and fiction. As a result of the transgressive merging of two levels, the intrusion of the extradiegetic narrator in El Metro on different planes creates a no-man's land narrative zone, ontologically speaking, that the reader and his effort and implication in the text can only decode.

It is then through the combination of the figure of "Mbom Mvet" with modern narrative techniques that Ndongo shapes ambiguity and the construction of a narrative space and discourse that enables him to focus on issues of migration. The very last words of the novel invite reflection: "Columbia, Missouri (United States), October 2005 " (p. 458). ${ }^{24}$ Who is signing this? Is the whole text a letter? In the para-text we find that the text is dedicated or addressed to a narratee: "To Pascual, an atypical immigrant". ${ }^{25}$ On the other hand, the real author, Donato Ndongo-Bidyogo, lived in 2005 in Columbia, invited there by the University of Missouri. This opens up the opportunity to penetrate into the intention of the real author. If we go back to Ndongo's idea about literature and the role of the writer as being useful to his community and not a mere artist, what we have is the last transgression of the novel - the irruption of the empiric author in the text, leaving us with the feeling of not knowing whether what has been narrated to the reader is a real history of a Black African postcolonial migrant or not.

\section{Final Considerations}

The foregoing analysis validates the proposition that liminality plays an important role in the poetics of our case study. It is evident the notions of limit and transgression are nuclear in the novel. The scope of application of liminality is particularly

\footnotetext{
${ }_{24}$ "Columbia, Missouri (Estados Unidos), Octubre de 2005".

25 "Para Pascual, un inmigrante atípico".
} 
remarkable upon a study of the rites and the psychological states of the protagonist. In all the cases that we have examined, the main function of the various liminal spaces such as boats, subways, and disputed territories is to emphasize the 'in-between' state of our protagonist, entrapped in a dichotomy between the values of tradition and modernity. On the plane of expression, liminality is often articulated in ambiguous atmospheres and sets of contrasts that evoke classical literary motifs. El Metro, written by the main author of Equatoguinean contemporary literature, serves to make us question our reality and find new ways to be creative in our thinking. The use of liminal narrative strategies reveals his epistemological point of view. Ndongo-Bidyogo shows us in his work that what helps us understand the seriousness of important social issues such as migration is, paradoxically, crossing borders into fictitious worlds.

\section{References}

Allen, D. (1998). Myth and Religion in Mircea Eliade. NY: Gardland. Ashley, K. (ed.) (I990). Victor Turner and the Construction of Cultural Criticism. Between Literature and Anthropology. Bloomington: Indiana University Press.

Bhabha, H.I994). The Location of Culture. London \& NY: Routledge.

Corbin, H. (2006). Cuerpo espiritual y tierra celeste. Madrid: Siruela.

Deflem, M. (I99I). "Ritual, Anti-Structure and Religion: a Discussion of Victor Turner's Processual Symbolic Analysis," Journal of the Scientific Study of Religion, 30, pp. I-25.

Eco, U (I992). Los limites de la interpretación. Barcelona: Lumen.

García, A. (2007). "Mis novelas son una propuesta de acción. Donato Ndongo-escritor," Diario ABC, 22 November [online].Available at: http://www.abc.es/hemeroteca/historico-22-I I-2007/abc /Canarias/mis-novelas-son-unapropuesta-de-accion-donato -ndongo-_-escritor_I64I397706708.html(Accessed:20September 20I7).

Genette, G. (I980). Narrative Discourse: An Essay on Method. Ithaca, NY: Cornell University Press. 
Hale, Thomas, A. (2007). Griots and Griottes. Masters of Words and Music. Indiana: Indiana University Press.

Koné, T. (2015). "The Ship as 'Cronotop' in El Metro of Donato Ndongo-Bidyogo," Perífrasis. Revista de Literatura, Teoría y Crítica, 6 (I I), pp. 38-52.

Lye, K. (2002). Encyclopedia of African Nations \& Civilizations. London: The Diagram Group.

Ndongo-Bidyogo, D. (2007). El Metro. Barcelona: Ediciones del Cobre.

- (2008). "El sueño," in Otabela, J. and Onomo, S. Entre estética y compromiso. La obra de Donato Ndongo-Bidyogo. Madrid: Universidad Nacional de Educación a Distancia, pp. 85-88.

Nomo, M. (2004). "Rasgos comunes y particularidades en cinco novelas negroafricanas postcoloniales en lenguas europeas: Rebeldia; Las tinieblas de tu memoria negra; The House Gun; Une vie de boy y O desejo de Kianda," Tonos. Revista electrónica de estudios filológicos, 8. Available at: http://www.um.es/tonosdigital /znum8/estudios/I 5-monique.htm (Accessed: 20 September 20I7)

O'connor,M.(2009).“AKiss ofDeath:ThePerils of Migration inDonato Ndongo's El Metro."Cádiz: Univeristy of Cadiz.Available at: https:// www.academia.edu/49 I 2479/A_Kiss_of_Death_The_Perils _of_Migration_in_Donato_Ndongo_s_El_Metro (Accessed: 20 September 20I7).

Otabela, J. and Onomo, A. (2008). Entre estética y compromiso. La obra de Donato Ndongo-Bidyogo. Madrid: Universidad Nacional de Educación a Distancia.

Phillips, T. (2015). Liminal Fictions in Postmodern Culture: The Politics of Self-Development. New York: Palgrave MacMillan

Pérez Firmat, G. (1986). Literature and Liminality. Festive Readings in the Hispanic Tradition. Durham: Duke University Press.

Piñero Ramírez, P. (ed.). (I995). Descensus ad inferos: La aventura de ultratumba de los héroes (de Homero a Goethe). Seville: University of Seville.

Rogers, H. (ed.) (2013) “'Between and Betwixt' Worlds: Spatial and Temporal Liminality in Video Art-Music," in The Oxford 
Handbook of New Audiovisual Aesthetics, Oxford: Oxford University Press, pp. 525-542.

Shcimanski, J. and Wolfe, S.F. (20I7). Border Aesthetics. Concepts and Intersections. New York: Berghahn Books. Series: Time and the World. Interdisciplinary Studies in Cultural Transformations.

Spariosu, M. (1997). The Wreath of Wild Olive. Play, Liminality, and the Study of Literature. NY: State University of New York Press.

Turner, V. (I970 "Betwixt and Between: The Liminal Period in Rites of Passage," in The Forest of Symbols. Aspects of Ndembu Ritual. Ithaca, NY: Cornell University Press, pp. 93-I I I.

Turner, V. (I99I). The Ritual Process: Structure and Anti-Structure. 7 th edn. Ithaca, NY: Cornell University Press

Ugarte, M. (2010). Africans in Europe. The Culture of Exile and Emigration from Equatorial Guinea to Spain. Urbana, Chicago and Springfield: University of Illinois Press.

Van Gennep, A. (2008). Los ritos de paso. Madrid, Alianza Editorial.

Viljoen, H. and van der Merwe, C. (eds.). (2006). Beyond the Threshold: Explorations of Liminality in Literature. New York: Peter Lang. 